\title{
Survey of fish consumption pattern in households of Shivamogga, Karnataka
}

\author{
Shashikanth H Majagi ${ }^{1 *}$ and Somashekar DS ${ }^{2}$ \\ ${ }^{1}$ Department of Studies in Zoology, Vijayanagara Sri Krishnadevaraya University, Ballari-583105, \\ Karnataka, India \\ ${ }^{2}$ PG Studies in Zoology, IDSG Government College, Chikkamagaluru-577102, Karnataka, India
}

Received: 06 July, 2020

Published: 20 July, 2020

*Corresponding author: Shashikanth H Majagi, Department of Studies in Zoology, Vijayanagara Sri Krishnadevaraya University, Ballari-583105, Karnataka, India, E-mail:smajgi@rediffmail.com

Keywords: Fish consumption; Sea food; Fisheries sector

https://www.peertechz.com

\section{Check for updates}

\begin{abstract}
The study was conducted to gather information on the fish consumption pattern among randomly selected households using a distinct questionnaire. The study revealed that much of the fish consuming communities prefer to consume fish regularly in their diet. Consumers commonly choice to consume fishes like Catla, Common carp, Rohu among the freshwater fish and Sardine, Mackeral and Prawns among sea food. The observation indicated that most of the respondents consume fish found to be once in a week compare to daily user. Survey showed that the range of fish species preferred (cost/ price of fish) mainly focused on the house hold income.
\end{abstract}

\section{Introduction}

Dietary habits of population in different regions of the world have been determined mainly by the availability of the local food and practices. Since, all foods are not of the same quality from a nutritional point of view, man's ability to meet his nutritional needs and maintain good health depends upon the type and quality of food stuffs available. Fish is a kind of food of excellent nutritional value and it makes a very significant contribution to the diet of many fish consuming communities in both developed and developing world. Flesh of fish is generally called as white meat and has agreeable taste and flavor. As far as food value is concerned, fish is more superior, having less amount of fat and more or equal protein as compared to other animal flesh consumed by human beings [1]. Fish meat and oil contains Vitamins, Omega 3 Polyunsaturated Fatty Acids (PUFA) and are helpful in controlling the eye and cardiovascular diseases [2]. Recent research has pointed out that the fish meat has anti-cancerous effects, minimized risk of heart diseases and as a result enhanced life expectancy.

Edible tissue of fish is appreciably greater than that of mutton, beef or poultry in nutritional aspects. The lean meat percentage in fish $(80.9 \%)$ is greater than chicken, broiler $(64.7 \%)$ and beef (choice grade, 51\%) [3]. The per capita fish consumption of $25.9 \mathrm{~kg} /$ year and $9.3 \mathrm{~kg} /$ year has been recorded in developed and developing countries respectively. It has been recorded that, the world average per capita fish consumption is $19 \mathrm{~kg} /$ year (Japan $86 \mathrm{~kg} /$ year, Mayanmar $13 \mathrm{~kg} /$ year, Srilanka $11 \mathrm{~kg} /$ year and Bangladesh $10 \mathrm{~kg} /$ year). The consumption of fish in India is increasing from $8.8 \mathrm{~kg}$ (1988) to $9 \mathrm{~kg}$ (2000) [4]. India position in per capita fish consumption is lowest position i.e., about $136^{\text {th }}$, it may be due to the fact that fish is eaten mostly by people residing rather in coastal areas. Among the states in India, highest in Lakshadweep, Andaman Island, Goa and Kerala (32 kg/year). States like Gujarat and Rajasthan fish is rarely consumed. It is necessary to develop data bases on different aspects of fisheries regarding productionconsumption patterns for formulating strategies for investment and development in the fisheries sector. According to [5], the obtained findings, both the UK and Singapore are potential targets for fishery export countries. However, the promotion strategies need to differ because food consumption is driven by different factors in each country. Hence, an attempt was made to collect information and data regarding the consumption pattern and frequency of fish consumption after making a random sampling survey among the households in the Shimoga city of Karnataka state.

\section{Materials and methods}

The study was carried out in certain areas of Shivamogga 
city by random sampling technique. The study area is located on the bank of river Tunga of Western Ghats. About one hundred and two numbers of households consuming fish were interviewed. The survey was conducted by means of sample census using a pretested semi-structure questionnaire, which is designed to collect sufficient reliable data includes different variables regarding frequency and consumption pattern of fish. The food frequency questionnaire has been dominan method for assessing food consumption in population studies [6].

\section{Result}

The present survey reveals that fish was an appreciated food by the local people. It was observed that $29.42 \%$ of people prefer fish as their first choice, $47.05 \%$ of people prefer fish as their second choice and $23.53 \%$ of people prefer fish as their third choice as per as consumption preference over poultry meat, mutton and beef. It was observed that majority of the respondents consume fresh water fishes $(60.78 \%)$ followed by marine fishes and prawns $(39.22 \%)$ (Table 1$)$. The varieties of fresh water fishes commonly consumed by the respondents of the study area includes Catla, Common carp, Rohu and Mrighal $(28.43 \%)$, Cat fishes $(15.69 \%)$ and other fresh water fishes $(11.76 \%)$, and with respect to marine fishes such as Sardine Mackerel, Hilsa and Bass (21.56 \%), Pomfret (2.95\%), Prawns $(8.83 \%)$ and other Sea fishes $(10.78 \%)$ as order of choice respectively (Table 1). Survey showed that the range of fish species preferred (cost/ price of fish) mainly focused on the house hold income and similar opinion was expressed by other workers $[7,8]$.

The frequency of consumption of fish food by the consumers, revealed that once in a week (30.39\%), once a fortnight, $(29.42$ $\%)$, once a month (18.62\%), occasional (14.70\%) and only $(6.87 \%)$ consumed fish on daily basis. Another important factor regarding freshness of the fish considered by the consumers showed that about $61.76 \%$ prefer fresh fish, $20.59 \%$ prefer frozen fish and about $17.65 \%$ prefer dry fish in their diet (Table 1 ).

\section{Discussion}

Analysis and interpretation of consumer perception further revealed that there is considerable demand for fish and there was immense scope for supply of fresh, dry as well as frozen fish. Demand for fish is likely to increase in the future, given the positive perception of fish as a food item in this part of the region and the recovery of previous consumption levels. The main future possibilities for increasing food fish supplies in the region include productivity enhancement programs in small water bodies, aquaculture development, and better utilization of small pelagic fish. Customers felt that they need authoritative source of information regarding the importance of fish food and consumption preference of fish species in their diet. So steps are needed by the fishery, food, health and other related departments to popularize the fish food in this area in particular and rest of the world in general. Table 2 depicts the purchase power of the assessed population. There is negative correlation between the purchase capacity and cost of the fish. Lower income group having much purchase power towards to
Table 1: Frequency and preference of choice of consumption of fish and sea food

\begin{tabular}{|c|c|c|c|}
\hline Time log & Percentage & Food particulars & Percentage \\
\hline Daily & $6.87 \%$ & $\begin{array}{c}\text { Catla, Common carp, Rohu and } \\
\text { Mrighal }\end{array}$ & $28.43 \%$ \\
\hline Once a week & $30.39 \%$ & Freshwater cat fishes & $15.69 \%$ \\
\hline Once a fortnight & $29.42 \%$ & Other Freshwater fishes & $11.76 \%$ \\
\hline Once a month & $18.62 \%$ & Sardine, Mackerel, Hilsa and Bass & $21.56 \%$ \\
\hline Occasional & $14.70 \%$ & Pomfret & $2.95 \%$ \\
\hline & & Prawns & $8.83 \%$ \\
\hline & & Other Sea foods & $10.78 \%$ \\
\hline
\end{tabular}

Table 2: Preference of choice of consumption of fish in relation to Purchase power.

\begin{tabular}{|c|c|c|c|c|}
\hline Fish Species & $\begin{array}{c}\text { Common } \\
\text { name }\end{array}$ & $\begin{array}{c}\text { Percentage of } \\
\text { Consumption }\end{array}$ & $\begin{array}{c}\text { Population } \\
\text { Income in Rs./- }\end{array}$ & $\begin{array}{c}\text { Purchasing } \\
\text { power } \%\end{array}$ \\
\hline Cyprinus carpio & $\begin{array}{c}\text { Catla } \\
\text { Common }\end{array}$ & $8.1 \%$ & $5000-10000$ & \\
\hline Labeo rohita & Rohu & $6.1 \%$ & $5000-10000$ & 80 \\
\hline Cirrhanus mrigala & Mrighal & $4.2 \%$ & $5000-10000$ & \\
\hline Freshwater cat fishes & & $15.69 \%$ & $>5000$ & \multirow{2}{*}{65} \\
\hline $\begin{array}{c}\text { Other Freshwater } \\
\text { fishes }\end{array}$ & & $11.76 \%$ & $>5000$ & \\
\hline Sardinella longiceps & Sardine, & $9.1 \%$ & $5000-10000$ & \multirow{2}{*}{42} \\
\hline Rastrelliger kanagurta & Mackerel & $5.2 \%$ & $5000-10000$ & \\
\hline Tenualosa ilisha & Hilsa & $3.4 \%$ & $5000-10000$ & \\
\hline Lates calcarifer & Bass & $3.86 \%$ & $>10,000$ & \\
\hline Pampus argenteus & Pomfret & $2.95 \%$ & $>10,000$ & \multirow{2}{*}{23} \\
\hline Fennerotaeus indicus & Prawns & $8.83 \%$ & $>>5000$ & \\
\hline and Penaeus sps. & Prawn & $10.78 \%$ & $>10000$ & \\
\hline Other Sea foods & & &
\end{tabular}

low cost fish. Similar studies are carried out by [9]. Majority of respondents $(72.1 \%)$ had shown their first preference for Rohu, second preference for Catla $(67.3 \%)$, and third preference for Mrigal (35.5\%). Similar findings were also reported by [10], where consumers of India and Bangladesh ranked Rohu, Catla and Mrigal as first, second and third preferred species respectively [11]. Study conducted in Karnataka also found that Rohu and Catla was the most preferred species and Mrigal was the least preferred species in both rural and urban areas.

Consumers commonly choice to consume fishes like Catla, Common carp, Rohu among the freshwater fish and Sardine, Mackeral and Prawns among sea food. The observation indicated that most of the respondents consume fish found to be once in a week compared to daily user. Survey showed that the range of fish species preferred (cost/ price of fish) mainly focused on the house hold income. Analysis and interpretation of consumer perception further revealed that there is considerable demand for fish and there was immense scope for supply of fresh, dry as well as frozen fish.

\section{References}

1. Rajayalakshmi R (1974) Fish and Seafood. Applied Nutration.II edn. Oxford and Indian Book House, New Delhi, India 1-24.

2. Kulikov PI (1978) Produuction of meat oil, Protein and Vitamin, Preparations in the fishing 2 ed. New Delhi. Amerinid Publishing Co. Pvt. Ltd 44-49. Link: https://bit.ly/32qswCW

3. Rath RK (1993) Freshwater aquaculture. Scientific publications. Jodhpur, India 1-66. Link: https://bit.ly/3932gQ9 
4. Venugopal V (2001) Nutrational importance of fishery products. In souvenir of Intrnat Symp on fish for Nutr Secur in the $21^{\text {st }}$ century $4-6^{\text {th }} .107-112$.

5. Supartini A, Oishi T, Yagi N (2018) Changes in Fish Consumption Desire and Its Factors: A Comparison between the United Kingdom and Singapore. Foods 7: 97. Link: https://bit.ly/3jjVHOu

6. Drewnowski A (2001) Diet Image: a new perspective on the food frequency questionnaire. Nutr Rev 59: 370-372. Link: https://bit.ly/3eBHrMM

7. Gopal N, Annamalai V (2001) Fish consumption profile at Cochin house holds. Fish Technol 38: 62-65. Link: https://bit.ly/32nxhNn

8. Ghosh and Cirnjib Adhikary (2006) Per capita fish consumption in Bhidarnagar (Salt Lake) area. Env Ecol 24S: 538-541.
9. Pardip CB, Cahandan G, Bipul KK (2017) Study of fish consumption patterns in Assam for development of market driven stratagies. Res J Chem Environ Sci 5 42-52. Link: https://bit.ly/3fKPdFr

10. Dey MM, Ferdinand JP, Ferdous Alam MD (2001) Production, accessibility, marketing and consumption patterns of freshwater aquaculture products in Asia: a cross country comparison."FAO Fish. Circular, No. 973, Rome, FAO 275. Link: https://bit.ly/2OBQHGm

11. Bhatt R (2001) Production, Accessibility and Consumption Patterns of Aquaculture Products in India. in 'Production, Accessibility, Marketing and Consumption Patterns of Freshwater Aquaculture Products In Asia: A Cross Country Comparison'. FAO Fisheries Circular 973 : 147-190. Link: https://bit.ly/30lEzys
Discover a bigger Impact and Visibility of your article publication with Peertechz Publications

\section{Highlights}

* Signatory publisher of ORCID

* Signatory Publisher of DORA (San Francisco Declaration on Research Assessment)

* Articles archived in worlds' renowned service providers such as Portico, CNKI, AGRIS, TDNet, Base (Bielefeld University Library), CrossRef, Scilit, J-Gate etc.

* Journals indexed in ICMJE, SHERPA/ROMEO, Google Scholar etc.

- OAI-PMH (Open Archives Initiative Protocol for Metadata Harvesting)

* Dedicated Editorial Board for every journal

* Accurate and rapid peer-review process

* Increased citations of published articles through promotions

* Reduced timeline for article publication

Submit your articles and experience a new surge in publication services (https://www.peertechz.com/submission).

Peertechz journals wishes everlasting success in your every endeavours.

Copyright: @ 2020 Majagi SH, et al. This is an open-access article distributed under the terms of the Creative Commons Attribution License, which permits unrestricted use, distribution, and reproduction in any medium, provided the original author and source are credited. 